\title{
Processes and evolution of the Pleistocene coastal sedimentary succession of Es Codolar (Southern Eivissa, Balearic Islands, Western Mediterranean): insights from soft sediment deformation structures.
}

Laura del Valle Villalonga ( $\square$ lauradelvalle.geo@gmail.com )

University of the Balearic Islands: Universitat de les Illes Balears https://orcid.org/0000-0003-3317-3007

Francesc Pomar

University of the Balearic Islands: Universitat de les Illes Balears

Joan J Fornós

University of the Balearic Islands: Universitat de les Illes Balears

Bernadí Gelabert

University of the Balearic Islands: Universitat de les Illes Balears

Alida Timar-Gabor

Universitatea Babeş-Bolyai: Universitatea Babes-Bolyai

\section{Research Article}

Keywords: Eivissa, Pleistocene, aeolianites, soft-sediment deformation structures

Posted Date: March 10th, 2021

DOI: https://doi.org/10.21203/rs.3.rs-226553/v1

License: (c) (i) This work is licensed under a Creative Commons Attribution 4.0 International License. Read Full License 


\section{Abstract}

We analyze the evolution of the undeformed Middle to Late Pleistocene deposits of Es Codolar (Southern Eivissa, Western Mediterranean). The outcrop records a succession characterized by the alternation of aeolian, colluvial and alluvial fan deposits and palaeosols that result in a complex stratigraphic architecture. In this area, aeolian beds, colluvial deposits and palaeosols are exposed along sea-cliffs for almost $500 \mathrm{~m}$, allowing detailed descriptions both of the general sedimentological and geomorphological features of the Middle to Late Pleistocene deposits. Several different types of soft-sediment deformation structures are described (Load-casts structures, injection structures, water-scape structures, rizoconcretions), which will help us in the understanding of the climatic evolution and the syn and post-depositional processes. In this way, main processes triggering the formation of these structures seem to be sea level changes together with a wetter environment during warmer climatic episodes.

\section{Introduction}

In the western Mediterranean, Pleistocene climatic changes resulted in several wet and dry periods (Martrat et al., 2004) combined with sea level fluctuations (Dorale et al., 2010). The past climate change record of Eivissa is recorded in the alternation of aeolianites and palaeosols, representing cold and warmer periods, respectively (Zazo et al., 1999; Del Valle et al., 2015; Del Valle, 2016).

Pleistocene sedimentary deposits of Eivissa (Balearic Islands), outcropping patchily along the coasts, provide an excellent record of glacial-interglacial cycles and eustatic fluctuations. The main representative deposits are the aeolianites, also present at other locations in the Balearic Islands (Clemmensen et al., 2001; Nielsen et al., 2004; Fornós et al., 2009; Fornós et al., 2012a; Pomar, 2016) and western Mediterranean (Andreucci et al., 2010 and 2014; Pappalardo et al., 2013; El-Asmar et al. 1994). The quick lithification of the aeolian deposits after subaerial exposure allows preserving a high-resolution sedimentological record (Fornós et al., 2012). Sedimentary successions containing Pleistocene coastal aeolianites at Eivissa use to display wide sorts of deposits characterized by colluvial facies and palaeosols and some thin shallow marine facies interbedded. In this sense, the variety of deposits and sometimes the rugged geomorphology of the coasts show a complex architecture (Pomar et al., 2015; Del Valle et al., 2016; Del Valle, 2016).

The main goal of this article is to present the sedimentary and climatic evolution of the Middle to Late Pleistocene deposits of Es Codolar (Southern Eivissa, Western Mediterranean). The outcrop records a succession characterized by the alternation of aeolian, colluvial and alluvial fan deposits and palaeosols that result in a tangled stratigraphic architecture. In this area, aeolian beds, colluvial deposits and palaeosols are exposed along sea-cliffs for almost $500 \mathrm{~m}$, allowing detailed descriptions both of the general sedimentological and geomorphological features of the Middle to Late Pleistocene deposits.

The second goal of this study is to describe for the first time the presence of soft-sediment deformation structures at Es Codolar succession and its implications for the evolution of the sedimentary succession. For this reason, identified soft-sediment deformation structures are described and deformation mechanisms are proposed. 
The term soft-sediment deformation refers to several processes which change and disrupt the sedimentary structures of unconsolidated sediments. Deformation usually occurs rapidly, close to the surface, during or shortly after the deposition, and before significant diagenesis (Owen et al., 2011). The soft-sediment deformation structures are widely described in the literature (e.g., Lowe, 1975, 1976, Allen, 1982; Mills, 1983; Owen, 1987, 1996; Maltman, 1994). Deformations features in aeolian deposits have long been recognized in the geologic record (e.g. Allen, 1982; Moretti, 2000; Olabode, 2014). They affect mostly multilayer deposits, especially sand-marl sequences, being concentrated along bedding planes or single beds, but they can as well spread through the whole deposit (Horváth et al., 2005). Most of them are related to a substantial decrease in shear resistance in water-saturated and unconsolidated sediments. They have been attributed to pore pressure changes most probably caused by fluid escape during fluidization and liquefaction (Lowe, 1975; Allen, 1982; Owen, 1987; Rossetti, 1999). Liquefaction and fluidization are the main processes which allow a temporary change from solid to liquid-like behavior in silts and sands (Allen, 1982). Many natural processes may induce liquefaction and fluidization such as uneven loading, overloading, wave-originated cyclical and/or impulsive stresses, sudden changes in earthquakes and water table (Allen, 1982; Owen, 1987, 1996; Molina et al., 1998; Rossetti, 1999; Moretti, 2000).

\section{Study area}

The Eivissa island is situated in the south-western Mediterranean Sea and it is considered the third largest $\left(571 \mathrm{~km}^{2}\right)$ and most Westerly island of the Balearic Archipelago (Fig. 1A). Geological structure of the island consists of a series of mainly Middle Triassic to Middle Miocene carbonate deposits thrust sheets) trending NE - SW (Rangheard, 1971). Muschelkalk limestone and dolomite, as well as Keuper marls and clays made up the Triassic materials of the island, whereas Jurassic limestone and dolomites and Cretaceous to Middle Miocene limestone overlie the Triassic materials and comprise the major reliefs of the island (Fig. 1B). Quaternary fluvial, alluvial and colluvial sediments fill the central basins, whereas Pleistocene coastal successions characterized by beaches to littoral aeolian and colluvial deposits crop out irregulary along the cliffed coasts (Del Valle et al., 2016a). Balearic Islands have been considered tectonically stable since the Pliocene with negligible or very little tectonic movements (Fornós et al., 2012 b; Just et al., 2011; Sàbat et al., 2011).

The outcrop of Es Codolar $\left(38^{\circ} 51^{\prime} 01^{\prime \prime} \mathrm{N}-1^{\circ} 22^{\prime} \mathrm{O} 3^{\prime \prime} \mathrm{E}\right)$ is extending continuously along $500 \mathrm{~m}$ of coastline and approximately $300 \mathrm{~m}$ inland. The Pleistocene succession is bounded at the base by an unconformity resting on folded upper Jurassic (Malm) marly limestones (Fig. 1C). The succession shows a complex alternation of colluvial-alluvial deposits built up by heterometric matrix to clast supported breccias, aeolianites and red paleosols (Del Valle, 2016). Es Codolar deposits are capping the steep slopes facing northwest of Puig des Falcó (144 m) and are showing a vertical cliff seaward shaped by wave erosion (Fig 1D).

\section{Methods}

We have conducted sedimentological analyses in order to identify the main facies and stratigraphic units composing the sequence. Additionally, we also have performed OSL analysis on aeolianites samples to unravel the palaeoenvironmental context that took place during the deposition. 


\section{Facies analysis}

Facies analysis has been performed acquiring additional six lithostratigraphic logs (Fig. 1D). Logs were analysed and correlated regarding major unconformities, bounding surfaces and the lateral continuity and architecture of the deposits. Units were defined in terms of brusque/abrupt facies changes.

Information on cross-bed dip direction for paleocurrent analyses was collected. Rock samples were taken for

grain size, carbonate content and mineralogical composition. Carbonate content was derived by hydrochloric acid etching by means of Bascomb calcimeter method. All collected samples showed a high degree of cementation, so they were cut and polished to perform grain size analysis. Images on polished faces were taken with a $4 x$ binocular magnifying and Motic Image 2.0 software to make observations on grain composition and size. Sample images were analysed by means of ImageJ open source software. For the remaining analyses, samples were crushed. The resulting powder was used to identify the colour by comparing dry sample powder and Munsell charts with artificial light. Mineralogical content was analysed through X-ray powder diffraction with the SIEMENS D5000 diffractometer using Cu Karadiation. Diffraction spectra were recorded from $3^{\circ}$ up to $65^{\circ} 2 \theta$ with lapses of $0.03^{\circ}$ every $3 s$ at $25^{\circ} \mathrm{C}$ and compiled in digital archives for later analysis. Using X-Powder v.2010.01.09 software, a semi-quantitative analysis was carried out comparing the results with the data base Difdata (Downs and Hall-Wallace, 2003).

\section{Soft-sediment deformation structures (SSD)}

Detailed photographs of the different sections displaying deformations were taken in order to describe the main features. The shape and geometry of the deformations were described by means of digital image reconstructions combined with the field observations (Chan and Brhun., 2014). Classifications of softsediment deformation structures can be used to establish morphologic and genetic systematizations. Thus, in our study area the following characteristics were identified: limited deformations among stratigraphic horizons, lateral continuity of SSD structures at appreciable distances and a confinement between nondeformed strata and its lithological association with psamitic-pelitic deposits. Soft-sediment deformation structures identified in this study were described and classified according the works of Rossetti, 1999; Moretti, 2000; Hórvath et al., 2005; Moretti and Sabato, 2007; Schillizzi et al., 2010; KoçTaşgin et al., 2011 and Ezquerro et al., 2016.

\section{Optically stimulated luminescence (OSL) dating}

OSL dating relies on the properties of some mineral grains such as quartz, but not only, to store energy resulted from exposure to the environmental radiation field during their burial within deposits, and its later release it in the form of light upon stimulation with light under controlled laboratory conditions. OSL has become a key chronological tool of Quaternary siliciclastic successions and recent contributions have highlighted the suitability of this method for aeolian sediments such as carbonate aeolianites (Murray and Clemmensen, 2000; Nielsen et al., 2004; Fornós et al., 2009; Anechitei-Deacu et al., 2018) and their possible correlation with the marine isotopic stages in order to obtain climatic information on the formation of these deposits and their geomorphological processes. The aeolianites collected at Es Codolar, contain between 1 
and $8 \%$ of siliciclastic grains, primarily quartz. Three rock samples $(\sim 70 \times 70 \times 50 \mathrm{~cm} ; 6 \mathrm{~kg})$ were collected for luminescence dating from aeolian deposits at Es Codolar. Aeolianite blocks were extracted from the stratigraphic layers considered to be representative of the succession. Blocks were detached in shadowed low light conditions and wrapped in lightproof material, labelled and documented and transported to the laboratory. The inner part of each sample was extracted in the laboratory and subsequently treated with $\mathrm{HCl}$ $(30 \%)$ and $\mathrm{H}_{2} \mathrm{O}_{2}(10 \%$ and $30 \%)$ for carbonate and organic matter removal. The remaining material was sieved to obtain material $<63 \mu \mathrm{m}$ and different fractions ranging from $63 \mu \mathrm{m}$ to $250 \mu \mathrm{m}$. The mineral fraction was subsequently etched with $40 \% \mathrm{HF}$ for $60 \mathrm{~min}$.

The equivalent dose measurements were undertaken using a Ris $\emptyset$ TL/OSL-DA-20 luminescence reader (Thomsen et al., 2006). The ${ }^{90} \mathrm{Sr}^{-90} \mathrm{Y}$ beta source was calibrated using gamma-irradiated calibration quartz supplied by Ris $\varnothing$ National Laboratory (Hansen et al., 2015). For these measurements the modified single aliquot regenerative protocol (Murray and Wintle, 2003) was applied, with preheat of $10 \mathrm{~s}$ at $220^{\circ} \mathrm{C}$, a cut heat to $180^{\circ} \mathrm{C}$ and an elevated temperature bleach of $40 \mathrm{~s}$ at $280^{\circ} \mathrm{C}$ at the end of each cycle. Radionuclide concentrations were derived by high-resolution gamma spectrometry and were transformed to dose rates using published conversion factors (Adamiec and Aitken, 1998). The cosmic ray contribution was evaluate using published formulae (Prescott and Hutton, 1994). Water content estimation was based on the difference in weight of the material from the inner part of the blocks, before and after oven drying, assuming a relative error of $25 \%$ for the time-averaged water content.

\section{Results}

\subsection{Stratigraphic succession and facies analyses}

Textural and compositional analysis have enabled to differentiate four major sedimentary deposits which represent aeolian and colluvial facies and two types of palaeosols.

\section{Aeolian facies}

Aeolian facies are characterized by very pale brown colour (HUE 10 YR 8/2), well-sorted, fine to mediumgrained sandstones, with large-scale trough cross stratification. The strata are $0.5 \mathrm{~m}$ to $3 \mathrm{~m}$ thick and are moderately disrupted by root casts $(0.50 \mathrm{a} 5 \mathrm{~cm}$ width and 0.10 to $1 \mathrm{~m}$ in length). Most of them are remains of moulds and calcified root casts. The facies composition is mainly medium-grained carbonate marine sand with very little terrigenous material (i.e. quartz grains). As stated to the diffraction analysis, calcite is the main mineral $(80 \%)$ and there is a minor presence of clay minerals. These deposits record the wind-transported marine carbonate sand trapping in front of a steep inland cliff.

\section{Colluvial facies}

Colluvial facies are characterized by massive reddish (HUE 5 YR 6/8) to pale brown (HUE 10 YR 8/3) silty matrix-supported breccias, composed of angular clasts forming millimetre to centimetre thick layers disrupted by calcrete levels. Large clasts are aligned downslope $\left(270^{\circ}\right.$ to $\left.330^{\circ} \mathrm{NW}\right)$, although the clasts 
display modal fabric orientation. Clasts come from the erosion of the basement composed of Jurassic marly limestones. Conforming to the diffraction analysis, the main composition is characterized by carbonates (72 $\%$ ). These deposits record episodic mass movements on slope surfaces characterized mainly by debris-flows transport.

\section{Palaeosols}

Two different types of palaeosols have been observed. The first one, around 20 to $40 \mathrm{~cm}$ thick is mainly composed of reddish silts (HUE 5 YR 6/8) with the presence of iron bands. According to the diffraction analysis, quartz is the main mineral $(20 \%)$ and there is a minor presence of clay minerals. The second one is characterized by massive silt and silty-sandy deposits with nodular forms and lots of bioturbation evidence with some root casts. Its colour is very pale brown (HUE 10 YR 8/4) and layers are 0.30 to $1.5 \mathrm{~m}$ thick, rich in carbonate $(71 \%)$. These palaeosols may represent periods of warmer environments characterized by very little erosion rates on slopes and the development of vegetation.

\section{Stratigraphic Units}

Es Codolar outcrop is composed of four units. Unit 1 (U1) consists of three colluvial levels interbedded with palaeosols. This unit is bounded at the base by an unconformity resting on the Jurassic basement. Thin calcretes are capping the colluvial-palaeosols sequence at the upper part.

In general, it is possible to observe three repeated sequences at U2, U3 and U4. All of them are made up from the base to the top by calcretes, palaeosol and/or colluvial deposits, dune and palaeosol. The lower palaeosol of each unit is filling up the rizoconcretion moulds of the immediately upper sandy level (Fig. 2).

\section{Soft-sediment deformation structures}

Eleven different types of well exposed soft-sediment deformation structures were distinguished in the Es Codolar. On characterizing the deformation structures, we considered lithology, size and geometrical characteristics (Fig. 2). Fifteen deformed levels have been observed.

\section{Contorted structures}

Contorted structure is used as a general term for all types of features with different degrees of crumpling or complicated folding of the laminae within sand beds (Brenchley and Newall, 1977). It was possible to define several types of contorted stratification: small-scale slump, large-scale slump, small-scale load structures, large-scale load-structures, deformed lamination, recumbent folds, convolute folds, ball and pillow, concave up path with consolidation lamination. In the study area, three deformation structures were observed: load structures and recumbent folds.

\section{Load structures}


Load structures are laterally continuous undulations at an interface between layers that varied in density with relatively denser sediment above and less dense below. Deformation is driven by the gravitational forces associated with the reverse density system and it is dominated by vertical displacements (Owen et al., 2011). Internal laminae are well-recognizable and, typically simulate the external circular form of the load-structures (Moretti and Sabato, 2007).

These forms are located in between carbonated sandstone and silts. The undulations are between $30-50 \mathrm{~cm}$ width and $20 \mathrm{~cm}$ to $30 \mathrm{~cm}$ high. They display a regular concave and convex morphology (wavy laminae) along the outcrop (Fig. 3). This deformation is present in all units of the outcrop within the sandstone levels, silty layers and calcretes levels. These structures extend continuously for $200 \mathrm{~m}$ along the coastline. The presence of deformation breccia $(\mathrm{Fb})$, flexi caves $(\mathrm{fc})$, convex structures with vertical axial plane characteristic by $20 \mathrm{~cm}$ in height and $13 \mathrm{~cm}$ in width is associated with these structures (Fig. 4 and 5).

\section{Recumbent folds}

These structures consist of cross-sets with overturned internal stratification, which forms recumbent folds with either horizontal or slightly inclined axial planes (Rossetti, 1999). These structures were developed in cross-bedded calcretes or loamy sands. Layers under the recumbent folds show sigmoid and concave forms. Recumbent folds at the uppermost part have parabolic morphology and there is no structure on the fold limbs. Recumbent folds are 15 to $20 \mathrm{~cm}$ in height and $30 \mathrm{~cm}$ wide. Fold axes are sub horizontal and generally oblique to the dip of the not deformed foresets strata. The folds have mainly rounded hinge zones. These structures can be observed at the level C2 of the Unit U1 (Fig.4).

\section{Intruded structures}

This term is used to group sandstone or silty-clay masses displaying different styles of elongate shapes that have intruded into other soft-sediment deformation structures (Lowe, 1975; Rossetti, 1999). The intruded structures are either conformable or disrupt bedding (Rossetti, 1999).

\section{Injection structures}

The injection structures are composed of root cast moulds with a size of 0.50 to $5 \mathrm{~cm}$ width and 15 to $25 \mathrm{~cm}$ height in sandstone levels. They are filled by reddish silts from the underlying palaeosol. The extrusive flows are low marked (ef). The base and upper contact are irregular (Fig. 4 and 5). The analysis of the mineralogical composition carried out both on the lower palaeosol and on the materials that fill the voids rizoconcretions moulds- of the aeolianites coincide. Conversely, there is no coincidence with the palaeosol located overlying the sandstone layer. These structures occur on two levels; in D1 (Unit U2) and level D2 (Unit U3). Nevertheless, we observed other injection structures within several levels on $\mathrm{Cl} 3$ (Unit U1), P4 (Unit U2) and P5 (Unit U3).

\section{Water-escape structures}

The term water-escape structure -hydroplastic mixing layer- is here used in a general sense to include all layers of sediment which have been internally deformed by hydroplastic flowage but which have not moved 
as a whole relative to surrounding sediments. Internally, liquefaction layers and pockets may show severely deformed primary structures (Fig. 6), nearly complete homogenization, or water-escape structures formed by the redistribution of grains during water-escape and re-sedimentation (Lowe, 1975; Trincardi et al., 2004). They are formed when sediment is transported by the expulsion of pore water or gas (Lowe, 1975; Owen et al., 2011).

The resulting structures show a range of 15 to $20 \mathrm{~cm}$ in height and 3 to $25 \mathrm{~cm}$ in width. Deformation is limited at the top by irregular palaeosol that shows extrusive flows. They are mainly represented by vertical conduits. The vertical development (perpendicular to the primary lamination) is very variable from linear to very irregular. The upper part of the conduits is often represented by conical morphology (wider downward) like volcanoes- that was probably located at the initial water sediment interface and they end upward with "vent"level. In figure 6 (A) water-escape structures in the sandstone beds forming diapirs or sand volcanoes can be observed. On the other hand, in figure 6 (B) the same structure but completely empty can be observed. These structures are observed in the sandstone levels D2 (Unit U3) and D3 (Unit U4), respectively.

\section{Flames and pillars}

Flame structures (Figure 4 and 7) developed at the interface between sandstone and silts are associated with large-scale load structures (KoçTaşgin et al., 2011). They consist of short, irregular and curved upward protuberances located along sharp boundaries formed between two deformed layers. Flame structures result from diapiric intrusion of fine sediments (Mills, 1983); they formed due to a gravitationally unstable density gradient.

Pillars (Figure 4 and 7) consist of discrete, straight to slightly sinuous, steeply inclined to vertical paths up to a few centimetres length (usually $<0.10 \mathrm{~m}$ ) and less than $0.03 \mathrm{~m}$ in diameter, which cut sharply through the deformed beds (Rossetti, 1999).

\section{Dyke and sill dyke}

This structure consists of masses of irregular, convolute laminated or massive sandstone that intruded sharply upwards into the overlying strata to form large (up to $0.65 \mathrm{~m}$ long and $0.29 \mathrm{~m}$ wide) elongated shapes. Although dykes are morphology similar to pillars, the latter term is reserved to describe discrete, straight to sinuous intrusions, while dykes are larger and show more irregular shapes (Rossetti, 1999). The dykes in the study area vary from vertical to steeply dipping and their basal edges attached to underlying sediment sources (Rossetti, 1999, Moretti and Sabato, 2007).

\section{Ice/sand-wedges}

Ice/sand-wedges forms by infilling of thermal constriction cracks in permafrost with water or sublimated ice crystal. A key feature of ice-wedge is the occurrence of vertical to steeply dipping laminae generally 0.5-5.0 mm thick (Mackay, 1986 in: Murton and Ballantyne, 2017; Wolfe et al., 2018). Cross-cutting relationships among laminae are common. Each lamina represents an ice vein formed by the filling of a single thermal contraction crack with ice. Thermal contraction cracks may fill with snow, ice, mineral particles or organic material, producing a variety of vein and wedge-shaped structures characterized as ice-wedges, sand wedges, 
soil wedges and composite (ice and sediment) wedges (Murton and Ballantyne, 2017). These structures have been observed at the levels P4 and P6; characterized by regular size (1 to $3 \mathrm{~cm}$ height and 10 to $14 \mathrm{~cm}$ width) (Fig. 7).

\section{Collapse structures}

The slope collapse in most cases occurs when an area has a steep slope and in the sedimentary succession some lower levels are saturated. The horizontality strata are affected, showing the movement of the upper materials due to the plastic behaviour of the lower levels, marked by a rupture of the original slope -rugged cut slump-. The lower levels are expected to transport the upper ones without affecting the original succession of layers. At the delay of movement derived from the compressive effect of the displacement front, fluids extrude forming cones or cut dikes (Fig. 8). Distinct deformations of this type initiate the movement as result of differences in the hydrostatic gradient (Strachan, 2002). Normally the occurrence of slumps requires the presence of a steep slope (KoçTaşgin et al., 2011).

Others collapse structures are formed when sediment can no longer be supported by its substrate. This may occur in association with karstic solution or substrate weakening (DeMille et al., 1964). The resulting structures can be very diverse (Fig.9), although they can be overlapped with load structures (Owen et al., 2011).

\section{Cryogenic brecciation}

These forms consist of numerous irregular rocks, isolated blocks, or sometimes oriented blocks (Fig. 4, 5 and 9). The blocks have an irregular size generally with 1 to $5 \mathrm{~cm}$ short axis and a 5 to $15 \mathrm{~cm}$ long axis. They are produced by cryotoplastic weathering (Lanfranco et al., 2014).

\section{Others associated structures}

Depositional structures may be disrupted and distinctive new structures may form as a result of chemical, physical, (e.g. crystal or concretion) and biological processes (e.g. plants roots, footprints) (Fig. 10).

\section{OSL ages}

Three OSL ages have been obtained in the Pleistocene succession of Es Codolar. The measured parameters, relevant for age calculation, are presented in Table 1. The samples were collected in aeolian facies beds in order to establish which the main aeolian events that took place here (Fig. 2). The first aeolian level dated corresponds to U2 and shows an age of $317 \pm 20 \mathrm{ka}$, coinciding with the cold stage MIS 10 . The next dated sample was from U3 which gave an age of $227 \pm 15 \mathrm{ka}$, coinciding with the cold stage MIS 8 . The last one dated was U4; this coincides with the end of the penultimate glacial stage MIS 6 with an age of $124 \pm 9 \mathrm{ka}$.

\section{Discussion}

The sedimentary records of Es Codolar reflect the alternation of Pleistocene cold and warm periods (Del Valle et al., 2016a, b; Del Valle, 2016). During the cold periods, sea level dropping led wind-transport inland of the 
marine sediments exposed on the continental shelf (Fornós et al., 2012a; Andreucci et al., 2014; Del Valle, 2016). During the relatively warmer periods, alluvial-colluvial deposits and palaeosols developed (Rose et al., 1999; Muhs et al., 2010; Fornós et al., 2012b; Andreucci et al., 2014; Wagner et al., 2014) and during the interglacial maximums the deposition of beach sediments were the most noticeable (Rose et al., 1999; Andreucci et al., 2010; Bardajíet al., 2009; Fornós et al., 2012b; Vicens et al., 2012).

According the OSL dating from the aeolian levels, the deposition of coastal dunes of units U2, U3 and U4 took place during the MIS 10, MIS 8 and MIS 6 respectively. This leads us to infer that the colluvial deposits and palaeosols of units U1 to U4 were formed during the interglacial stages MIS 11, MIS 9, MIS 7 and MIS 5 , respectively.

The study of soft-sediment deformation structures helps us to understand the sedimentary and climatic evolution of Es Codolar sequence. In this sequence, the presence in loamy sandstones beds of ice-sand wedges at levels P4 and P6 (Fig. 2), located just above the aeolian levels D2 and D3, confirms the occurrence of several periods of cold temperatures just after the deposition, during the glacial stage, of D2 and D3 aeolian levels. But these periods of cold temperatures occurred even during the interglacial stages, as shown by the presence of cryogenic breccias at levels P2 and P3 (located below the D1 aeolian level), deposited during the interglacial stage MIS 11.

On the other hand, in Es Codolar sequence, the soft sediment deformation structures are considerably larger and frequent into the lower levels than into the upper levels, pointing to an increasing load as responsible for the development of these structures. In this way structures formed after the deposition of the majority of the sedimentary levels. Moreover, because the liquefaction structures formed in water-saturated sediments it is more probable than these structures were formed during the interglacial stages, when sea level is higher, the rainfall increase and therefore there is a greater presence of vegetation. In figure 1 a coastal lagoon is observed near the outcrop, indicating the significant proximity of the water table. Thus, in Es Codolar, during the interglacial stages the sediments were saturated due to both a wetter environment and a higher water table, being the maximum high during MIS 5 , when sea level was nearly $3 \mathrm{~m}$ higher than today (Polyak et al., 2018). Because of these two reasons (1st- maximum sea level during MIS 5 and 2nd- deformation structures larger and more frequent at the lower levels), we infer that the soft sediment deformation structures were formed at the end of MIS 6 to MIS 5, after the deposition of aeolian unit U4.

Based on the discussion above, Figure 12 shows the evolution of the Pleistocene sedimentary sequence of Es Codolar. After the formation of the colluvial beds at the base of the sequence, the first aeolian level was deposited during a relative sea-level drop in MIS 10 (Fig. 13). Bioturbation structures developed in this level, with dominant palaeo - wind currents from SSW to NNE (Fig. 12-A). During MIS 9 a thin sequence $(1 \mathrm{~m})$ of colluvial and palaeosol sediments was deposited on top of the previous aeolian level. A second aeolian level was formed during MIS 8 under a predominant wind from $S$ to N. Bioturbation structures also developed into this level (Fig. 12-C). During MIS 7, characterized by a higher water level and humidity than in MIS 6 (Fig. 13), a thin sandy palaeosol was formed, with some intercalation of colluvial beds (Fig. 12-D). The upper aeolian level was emplaced during MIS 6 and has the same characteristics as the previous aeolian beds. At the end of this period soft sedimentary deformation structures formed. These structures are larger and frequent in lower levels because of the increasing load as we go lower in the stratigraphic series. The sequence of Es 
Codolar ends with the deposition of a thin sequence of sandy and loamy paleosols and calcretes corresponding to MIS 5 . This combined with an intensification in the pluviometry and the rise of the water table, produced fluidization structures of these palaeosol into the upper aeolian level.

\section{Conclusions}

Results of sedimentary analyses and OSL dating allowed distinguishing the effects of climatic fluctuations during the sedimentation of these Pleistocene deposits. Due to the strong climatic signal registered in Es Codolar sequence and the absence of significant tectonic movement, changes in the environmental agents (i.e. arid-wetter periods and sea level changes) are the most plausible processes controlling the described sediment deformations. The common factor in the formation of soft-sediment structures is that all the origin sediments went through liquefaction-fluidization, which appears to be mostly triggered by a combination of sea level rise and increasing humidity during interglacial periods. It should not be forgotten however that wave erosion at the hillslope could also contribute to instability of the outcrop. On the other hand, during glacial periods the encroaching of new dune fields on Es Codolar added up thick sedimentary bodies to the outcrop package that could have increased the overloading processes. The colder conditions during these periods could have boosted the cryogenic-related structures. Which help us in the understanding of the climatic evolution and the syn and post-depositional processes. The main processes triggering the formation of these structures seem to be sea level changes together with a wetter environment during warmer climatic episodes.

\section{Declarations}

\section{ACKNOWLEDGEMENTS}

This work was supported by the research fund project, CGL2013-48441-P andCGL2016-79246-P of the MINECO (Spanish Government). A. Timar-Gabor acknowledges the financial support from PN-III-P3-3.6H2020-2016-0015. We would like to thank Joan Cifre andValentina Anechitei-Deacu for sample preparation and Lluís Gómez-Pujol for visit the outcrop with us and their comments.

\section{References}

Adamiec G, Aitken MJ (1998) Dose-rate conversion factors: update. Ancient TL 16: 37- 50.

Allen JRL (1982) Sedimentary Structures: Their Character and Physical Basis, Vol II. Elservier: New York; 663.

Allen JRL, Banks NL (1972) An interpretation and analysis of recumbent folds deformed cross-bedding. Sedimentology 19:257-283.

Andreucci S, Clemmensen LB, Murray A, Pascucci V (2010) Middle Late Pleistocene coastal deposits of Alghero, northwestern Sardinia (Italy): chronology and evolution. Quaternary International 222:3-16.

Andreucci S, Panzeri L, Martini P, Maspero F, Martini M, Pascucci V (2014) Evolution and architecture of a West Mediterranean Upper Pleistocene to Holocene coastal apron-fan system. Sedimentology 61:333-361. 
Brenchely PJ, Newall G (1977) The significance of contorted bedding in the Upper Ordovician sediments of the OSLO region, Norway. Journal of sedimentology and petrology 47:819-833.

Bryant G, Cushman R, Nick K, Miall A (2016) Paleohydrologic controls on soft-sediment deformation in the Navajo Sandstone. Sedimentary Geology 344:205-221.

Camoin GF, Webster JM (2015) Coral reef response to Quaternary sea-level and environmental changes: State of Science. Sedimentology 62:401-428. https://doi.org/10.1111/sed.12184.

Chan A, Bruhn L (2014) Dynamic liquefaction of Jurassic sand dunes: processes, Origins, and implications. Earth Surface Processes and Landforms 39:1478-1491.

Clemmensen LB, Lisborg T, Fornós JJ, Bromley RG (2001) Cliff-front aeolian and colluvial deposits, Mallorca, Western Mediterranean: a record of climatic and environmental change during the last glacial period. Bulletin of the Geological Society of Denmark 48:217-232.

Collinson J, Mountey N, Thompson D (2006) Sedimentary structures. Terra Publishing; 3 Rev. Ed. Edition. 299 pp.

Del Valle L (2016) El registre sedimentari eòlic del Plistocèlitoral d'Eivissa. PhD thesis, Universitat de les Illes Balear, $286 \mathrm{pp}$.

Del Valle L, Fornós JJ, Gómez-Pujol L, Pomar F, Anechitei-Deacu V, Timar-Gabor A (2015) El Pleistoceno medio de la zona de Cala Bassa (Eivissa, Mediterráneo Occidental): Evolución paleoclimática. Geotemas 15:169-172.

Del Valle L, Gómez-Pujol L, Fornós JJ, Timar-Gabor A, Anechitei-Deacu V, Pomar F (2016a) Middle to Late Pleistocene dunefields in rocky coast settings at Cala Xuclar (Eivissa, Western Mediterranean): Recognition, architecture and luminescence chronology. Quaternary International 407:4-13.

Del Valle L, Pomar F, Fornós JJ, Gómez-Pujol L (2016b) Estructuras de deformación de la secuencia sedimentaria pleistocena costera de Es Codolar (Eivissa, Mediterráneo occidental). Geotemas 17:15-18.

DeMille G, Shouldice JR, Nelson NW (1964) Collapse structures Related to the Prairie Formation, Saskatchewan. Geological Society of American Bulletin 75(4):307-316.

Diaz de Neira A, Garcia de Domingo A, Gil I, Cabra P, Ruíz P, (1997) Mapa Geológico de España. Escala 1:200.000. Ibiza 65/09-08 Instituto Geológico y Minero de España.

Dorale JA, Onac PB, Fornós JJ, Ginés J, Ginés A, Tuccimei P, Peate DW (2010) Sea-level Highstand 81,000 Years Ago in Mallorca. Science 327:860-863.

Downs RT, Hall-Wallace M (2003) The American Mineralogist Crystal structure data base. American Mineralogist 88:247-250. 
El-Asmar H (1994) Aeoloianite sedimentation along the northwestern coast of egipt: evidence for middle to late quaternary aridity. Quaternary Science Reviews 13:699-708.

Ezquerro L, Moretti M, Liesa CL, Luzón A, Pueyo EL, Simón JL (2016) Control son space-time distribution of Soft-sediment deformation structures: Applying palaeomagnetic dating to approach the apparent recurrence period of paleoseisms at the Conard Fauld (eastern Spain). Sedimentary Geology 344:91-111.

Flügel E (2014) Microfacies of Carbonate Rocks. Analysis, Interpretation and Application. Springer. Berlin, pp. 976

Fornós JJ, Clemmensen LB, Gómez-Pujol L, Ginés A, Ginés J (2012a) Pleistocene eolianites and low sea levels. A field trip. In: Mallorca: A Mediterranean Benchmark for Quaternary studies (Eds: A. Ginés, J. Ginés, L. Gómez-Pujol, B.P. Onac, and Fornós, J.J.). Mon. Soc. Hist. Nat. Balears 18:85-110.

Fornós JJ, Clemmensen LB, Gómez-Pujol L, Murray A (2009) Late Pleistocene carbonate aeolianites on Mallorca, Western Mediterranean: a luminescence chronology. Quaternary Science Reviews 28:2697-2709.

Fornós JJ, Ginés A, Ginés J, Gòmez-Pujol L, Gràcia F, Merino A, Onac BP, Tuccimei P, Vicens D (2012b) Upper Pleistocene deposits and karst features in the littoral landscape of Mallorca Island (Western Mediterranean): A field trip. In: Mallorca: A Mediterranean Benchmark for Quaternary studies (Eds: A. Ginés, J. Ginés, L. Gómez-Pujol, B.P. Onac, and Fornós, J.J.). Mon. Soc. Hist. Nat. Balears 18:163-220.

Gil J, García de Domingo A, Díaz de Neira A, Cabra P (1997) Mapa Geológico de Ibiza y Formentera a escala 1:100.000 (Geológico de Ibiza-Formentera 100).

Hansen V, Murray A, Buylaert JP, Yeo EY, Thomsen KJ (2015) A new irradiated quartz for beta source calibration. Radiation Measurements 81:123-127.

Herbert TD, Peterson LC, Lawrence KT, Liu Z (2010) Tropical ocean temperatures over the past 3.5 million years. Science 328:1530-1534.

Horváth Z, Michéli E, Mindszenty A, Berényi-Üveges J (2005) Soft-sediment deformation structures in Late Miocene-Pleistocene sediments on the pediment of the Mátra Hills (Visonta, Atkár, Verseg): Cryoturbation, load structures or seismites? Tectonophysics 410:81-95.

Jones AP, Omoto K (2000) Towards establishing criteria for identifying trigger mechanisms for soft-sediment deformation: a case study of Late Pleistocene lacustrine sands and clays, Onikobe and Nakayamadaira Basins, northeastern Japan. Sedimentology 47:1211-1226.

Just J, Hübscher C, Betzler C, Lüdmann T, Reicherter K (2011) Erosion of continental margins in the Western Mediterranean due to sea-level stagnancy during the Messinian salinity crisis. Geo-Marine Letters 31:51-64.

KoçTaşgin CK, Orhan H, Tükmen I, Aksoy E, (2011) Soft-sediment deformation structures in the late Miocene Şelmo Formation around Adiyaman area, Southeastern Turkey. Sedimentary Geology 235:277-291. 
LanFranco M, Rapisardi E, Giardino M (2014) A missed Window of Opportunity. Chapter 36.185 to 190 In: Engineering Geology for Society and Territory -V. 7: Education, Professional Ethics and Public Recognition of Engineering Geology. Springer (Eds G. Lollino, M. Arattano, R. Oliveira and S. Peppoloni. 274 pp.

Lowe DR (1975) Water-escape structures in coarse grained sediments. Sedimentology 22:157-204.

Lowe DR (1976) Subaqueous liquefied and fluidized sediment flows and their deposits. Sedimentology 23:285-308.

Lowe JJ, Walker M (2015) Reconstructing quaternary environments. Routledge editor. Third edition. Chapter 3:117-131.

Maltman AJ (1994) The Geological Deformation of Sediments. Chapman and Hall London. 326 pp.

Martrat B, Grimalt JO, López-Martínez C, Cacho I, Sierro FJ, Flores JA, Zahn R, Canals M, Curtis JH, Modell DA (2004) Abrupt temperature changes in the Western Mediterranean over the past 250,000 years. Science 306:1762-1765.

McKee ED, Douglas JR, Rittenhouse S (1971) Deformation of lee-side laminae in eolian dunes. Geol. Soc. Am. Bull. 82:359-378.

Mills PC (1983) Genesis and diagnòstic value of soft-sediment deformation structures- a review. Sedimentary Geology 35:83-104.

Molina JM, Alfaro P, Moretti M, Soria JM (1998) Soft-Sediment deformation structures induced by cyclic stress of storm waves intempestites (Miocene, Guadalquivir basin, Spain). Terra Nova 10:145-150.

Moretti M (2000) Soft-sediment deformation structures interpreted as seismites in middle-late Pleistocene aeolian depòsits (Apulian foreland, Southern Italy). Sedimentary Geology 135:167-179.

Moretti M, Sabato L (2007) Recognition of trigger mechanisms for soft-sediment deformation in the Pleistocene lacustrine deposits of the Sant Arcangelo Basin (Southern Italy): Seismic shock vs. Overloading. Sedimentary Geology 196:31-45.

Muhs DR, Budahn J, Avila A, Skipp G, Freeman J, Patternson D (2010) The role of African dust in the formation of Quaternary soils on Mallorca, Spain and implications for the genesis of Red Mediterranean soils. Quaternary Science Reviews 29:2518-2543.

Murray AS, Clemmensen LB (2000) Luminescence dating of Holocene aeolian sand movement, Thy, Denmark. Quaternary Science Reviews 20:751-754.

Murray AS, Wintle AG (2003) The single aliquot regenerative dose protocol: potential for improvements in reliability. Radiatiation Measurements 37:377-381.

Murton JB, Ballantyne CK (2017) Periglacial and permafrost ground models for Great Britain. Gniffths, J.S., Martin, C.J. (Eds). Engineering Geology and Geomorphology of Glaciated and Periglaciated Terrains- 
Engineering Group Working Party Report. Geological Society, London. Engineering Geology Special Publications 28:501-597, https://doi.org/10.1144/EGSP28.5 Chapter 5.

Nielsen KA, Clemmensen LB, Fornós JJ (2004) Middle Pleistocene magnetostratigraphy and susceptibility stratigraphy: data from a carbonate aeolian system, Mallorca, Western Mediterranean. Quaternary Science Reviews 23:1733-1756.

Olabode S (2014) Soft sediment deformation structures in the Maastrichtian. Ajali Formation, Western Flank of Amambrer Basin, Southern Nigeria. Journal of African Earth Science 89:16-30.

Owen G (1996) Experimental soft-sediment deformations: structures formed by liquefaction of unconsolidated sands and some ancient examples. Sedimentology 43:279-293.

Owen G (1987) Deformation processes in unconsolidated sands In: Deformation of Sediments and Sedimentary Rocks (Eds M.E. Jones, and R.M.F. Preston). Geol. Soc. (London) Spec. Pub. No. 29: 11-24.

Owen G (1995) Soft-Sediment deformation in Upper Proterozoic Torridonian Sandstones (Applecross Formation) at Torridon Northwest Scotland. J. Sediment Res., AGS 495-504.

Owen G, Moretti M (2011) Identifying triggers for liquefaction-induced soft-sediment deformation in sands. Sedimentary Geology 235:141-147.

Owen G, Moretti M, Alfaro P (2011) Recognizing triggers for soft-sediment deformation: Current understanding and futur directions. Sedimentary Geology 235:133-140.

Pappalardo M, Chelli A, Ciampalini A, Rellini I, Biagioni F, Brückner H, Fülling A, Firpo M (2013) Evolution of an Upper Pleistocene aeolianite in the northern Mediterranean (Liguria, NW Italy). Ital. J. Geosci. 132(2):290-303.

Polyak VJ, Onac BP, Fornós JJ, Hay C, Asmerom Y, Dorale JA, Ginés J, Tuccimei P, Ginés A (2018) A highly resolved record of relative sea level in the western Mediterranean Sea during the last interglacial period. Nature Geoscience 11:860-864, doi:10.1038/s41561-018-0222-5.

Pomar F (2016) Arquitectura i fàcies deposicionals de la interferència entre la sedimentació al·luvial, col-luvial i eòlica a les Illes Balears durant el Pleistocè Superior: Implicacions paleoclimàtiques. PhD Thesis. $375 \mathrm{pp}$.

Pomar F, Del Valle L, Fornós JJ, Gòmez-Pujol L (2015) Registro sedimentario Litoral del Pleistoceno en las Islas Baleares (Mediterráneo Occidental): implicaciones paleoclimáticas. VIII Jornadas de Geomorfología Litoral. Geotemas 15:65-68.

Prescott JR, Hutton JT (1994) Cosmic ray contributions to dose rates for luminescence and ESR dating: Large depths and long terms variations. Radiation Measurements 23(2-3):497-500.

Rangheard Y1971. Etude géologique des îles d'Ibiza et de Formentera (Baléares). Memorias del IGME, 82:1340 . 
Roberts DL, Bateman MD, Murray-Wallace CV, Carr AS, Holmes PJ (2008) Last interglacial fossil elephant trackways dated by OSL/AAR in coastal aeolianites Still Bay, South Africa. Palaeogeography, Palaeoclimatology, Palaeoecology 257:261-279.

Rohling EJ, Grant K, Bolshaw M, Roberts AP, Siddall M, Hemleben C, Kucera M (2009) Antarctic temperature and global sea level closely coupled over the past five glacial cycles. Nature Geoscience 2:500-504. https://doi.org/10.1038/ngeo557.

Rose J, Meng X, Watson C (1999) Palaeoclimate and palaeoenvironmental responses in the western Mediterranean over the last 140 ka: evidence from Mallorca, Spain; Journal of the Geological Society, Londonn156:435-448.

Rossetti DF (1999) Soft-sediment deformation structures in late Albian to Cenomanian depòsits, São Luís Basin, northen Brazil: evidence for palaeoseismicity. Sedimentology 46:1065-1081.

Sàbat F, Gelabert B, Rodríguez-Perea A, Jiménez J (2011) Geological structure and evolution of Majorca: Implications for the origin of the western Mediterranean. Tectonophysics 510:217-238.

Servera J (1997) Els sistemes dunars litorals de les Illes Balears. PhD Thesis, Universitat de les Illes Balears 904 pp.

Shackleton NJ, Backman J, Zimmerman H, Kent DV, Hall MA, Roberts DG, Schnitker D, Baldauf JG, Desprairies A, Homrighausen R, Huddlestun P, Keene JB, Kaltenbach AJ, Krumsiek KAO, Morton AC, Murray JW, Westberg-Smith J (1984) Oxygen isotope calibration of the onset of icerafting and history of glaciation in the North Atlantic region. Nature 307:620-623.

Shillizzi R, Luna L, Falco Jl (2010) Estructuras de deformación (¿Sismitas?) en la formación río Negro, provincia de río Negro, Argentina. Latin American Journal of Sedimentology and Basin Analysis 17 (1):17-32.

Silva PG, Zazo C, Bardají T, Baena J, Lario J, Rosas A, Van der Made, J (2009) Tabla cronostratigràfica del Cuaternario de la Península Ibérica, v.2. AEQUA. Available at: www.aequa.es (02/10/2018)

Sivan D, Porat N (2004) Evidence from luminescence for Late Pleistocene formation of calcareous aeolianite (kurkar) and paleosol (hamra) in the Carmel Coast, Israel. Palaeogeogr. Palaeoclimatol. Palaeoecol. 211:95106.

Strachan L (2002) Slump initiated and controlled syndepositional sandstone removilization: and exemple from the Namurian of Country Clare, Ireland. Sedimentology 49:25-41.

Thomsen KJ, Bøtter-Jensen L, Denby P, Moska P, Murray AS (2006) Developments in luminescence measurements techniques. Radiation Measurement 41:768-773.

Trincardi F, Cattaneo A, Correggiari A, Ridente D (2004) Evidence of soft sediment deformation, fluid escape, sediment failure and regional weak layers within the late Quaternary mud deposits of the Adriatic Sea. Marine Geology 213:91-119. 
Vicens D, Gràcia F (2012) Quaternary beach deposits in Mallorca: paleontological and geormorphological data. In: In: Mallorca: A Mediterranean Benchmark for Quaternary studies (Eds: A. Ginés, J. Ginés, L. GómezPujol, B.P. Onac, and Fornós, J.J.). Mon. Soc. Hist. Nat. Balears 18:55-83.

Waelbroeck C, Labeyrie L, Michel E, Duplessy JC, Mcmanus JF, Lambeck K, Balbon E, Labracherie M (2002) Sea-level and deep-water temperature change derived from benthic foraminifera isotopic records. Quaternary Science Reviews 21:295-305.

Wagner S, Eckmeier E, Skowronek A, Günster N (2014) Quaternary paleosols and sediments on the Balearic Islands as indicators of climate changes. Catena 112:112-124.

Waldron JWF, Gagnon JF (2010). Recognizing Soft-sediment structures in deformed rocks of orogens. Journal of Structural Geology 33(3):271-279. Doi: 10.1016/j.jsg.2010.06.015. in press.

Winkler EM (1997) Stone in Architecture. Properties and Durability. Springer., Berlin pp 313

Wolfe S, Morse PD, Neudorf C, Kokelj SV, Lian OB, O’Neill HB (2018) Contemporary sand wedge development in seasonally frozen ground and paleoenvironmental implications. Geomorphology 308:215-229.

Zazo C (1999) Interglacial sea levels. Quaternary International 55:101-113.

\section{Table}

Table1. Optically stimulated luminescence dating of Pleistocene aeolianites at Es Codolar (Eivissa). Summary of the luminescence and dosimetry data used for OSL age calculation. The ages have been obtained using $63-250 \mu \mathrm{m}$ quartz, with the weighted average values presented here. The uncertainties associated with the equivalent doses and dosimetry (radionuclide specific activities and total dose rates) data are random. $\mathrm{n}$ represents the number of aliquots used for equivalent dose estimation. The equivalent dose is computed as the unweighted mean of the equivalent dose distribution. Overdispersion is given. The uncertainties mentioned with the optical ages are the overall uncertainties (random and systematic). Systematic errors include: $2 \%$ beta source calibration, 3\% conversion factors, $5 \%$ attenuation and etching factors, 3\% gamma, spectrometer calibration, 15\% cosmic radiation. All uncertainties represent $1 \sigma$.

\begin{tabular}{|c|c|c|c|c|c|c|c|c|c|c|c|c|c|}
\hline & $\begin{array}{c}\text { Sample } \\
\text { code }\end{array}$ & $\begin{array}{c}\text { Depth } \\
(\mathrm{cm})\end{array}$ & $\begin{array}{l}\text { Grain } \\
\text { Size } \\
(\mu \mathrm{m})\end{array}$ & $\begin{array}{c}\text { Water } \\
\text { content } \\
(\%)\end{array}$ & $\begin{array}{c}\text { ED } \\
(\mathrm{GY})\end{array}$ & $\begin{array}{c}\mathrm{U}-\mathrm{Ra} \\
(\mathrm{Bq} / \mathrm{Kg})\end{array}$ & $\begin{array}{c}\text { Th } \\
(\mathrm{Bq} / \mathrm{kg})\end{array}$ & $\begin{array}{c}\mathrm{K} \\
(\mathrm{Bq} / \mathrm{kg})\end{array}$ & \begin{tabular}{|c|} 
Total \\
Random \\
error \\
$(\%)$ \\
\end{tabular} & $\begin{array}{c}\text { Total } \\
\text { Systematic } \\
\text { error (\%) }\end{array}$ & $\begin{array}{c}\text { Total } \\
\text { dose rate } \\
(\mathrm{Gy} / \mathrm{Ka})\end{array}$ & $\begin{array}{l}\text { Age } \\
(\mathrm{Ka})\end{array}$ & MIS \\
\hline Codolar & M\#22\# & 840 & $\begin{array}{l}63- \\
250\end{array}$ & 0.7 & $\begin{array}{c}154 \pm 4 \\
n=9\end{array}$ & $9.8 \pm 0.3$ & $4.1 \pm 0.2$ & $37.9 \pm 2.5$ & 3.27 & 5.48 & $0.49 \pm 0.01$ & $317 \pm 20$ & 10 \\
\hline Eivissa & M\#24\# & 730 & $\begin{array}{l}63- \\
250 \\
\end{array}$ & 18 & $\begin{array}{c}100 \pm 2 \\
n=10\end{array}$ & $10.1 \pm 0.1$ & $3.4 \pm 0.1$ & $45.8 \pm 3.6$ & 2.97 & 5.66 & $0.44 \pm 0.01$ & $227 \pm 15$ & 8 \\
\hline Profile & M\#26\# & 220 & $\begin{array}{l}63- \\
250\end{array}$ & 14.3 & $\begin{array}{l}59 \pm 2 \\
n=10\end{array}$ & $9.8 \pm 0.2$ & $3.1 \pm 0.3$ & $33.7 \pm 3.1$ & 3.93 & 6.48 & $0.48 \pm 0.01$ & $124 \pm 9$ & 6 \\
\hline
\end{tabular}

\section{Figures}




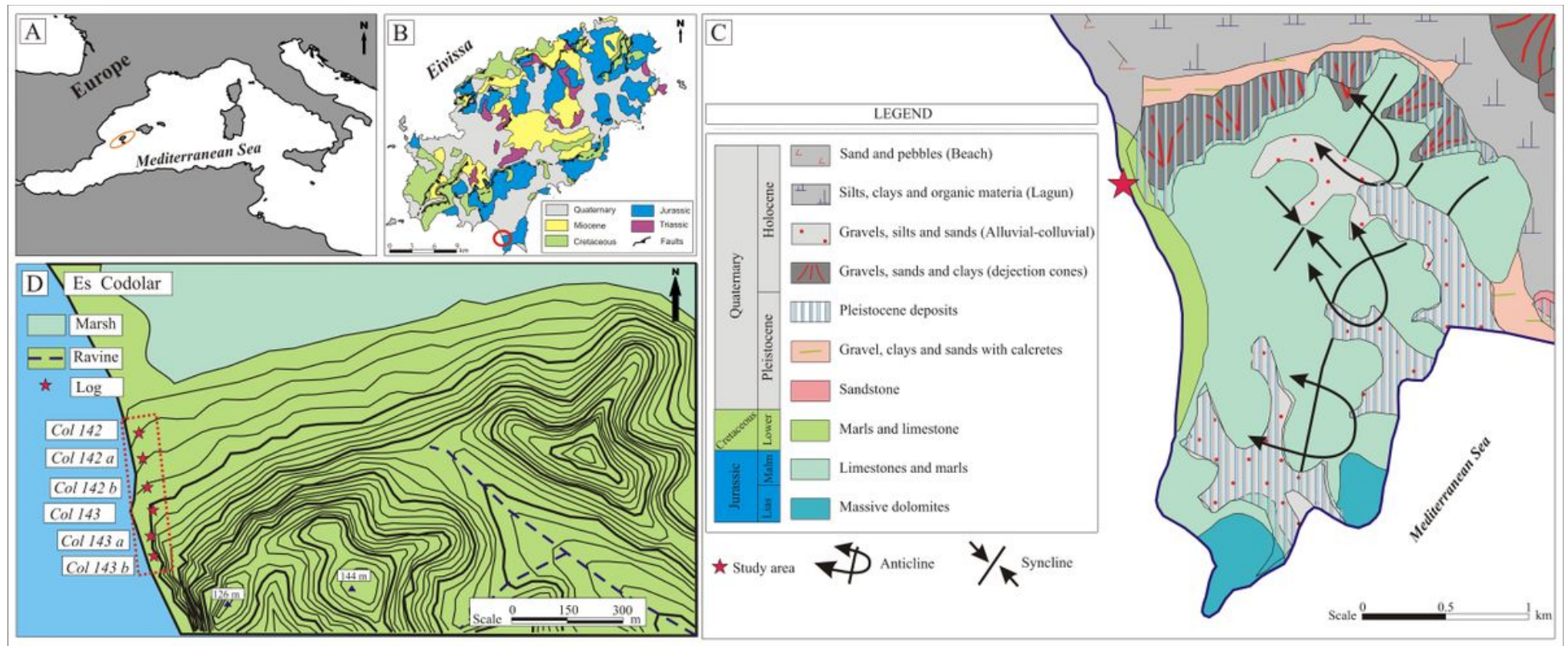

Figure 1

A) Location of the studied area; B) geological map of Eivissa modified by Diez de Neira et al., 1997 C) detail of geological map of the studied area modified from Gil et al., 1997 and D); topographic map and stratigraphic logs from the studied area. 


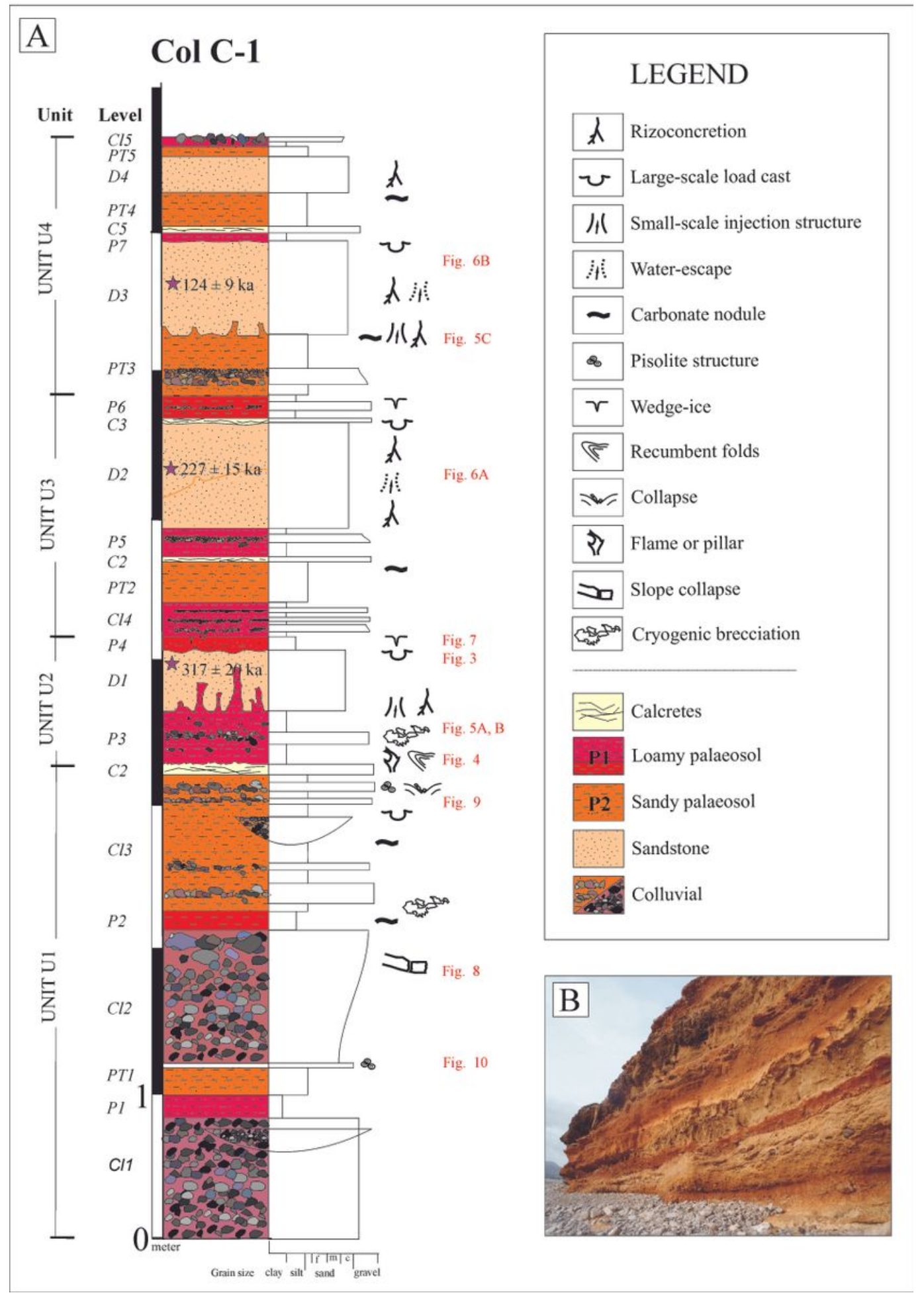

Figure 2

A) Lithostratigraphic log and main facies characteristic of Pleistocene Es Codolar Formation. B) Photography of the outcrop. 

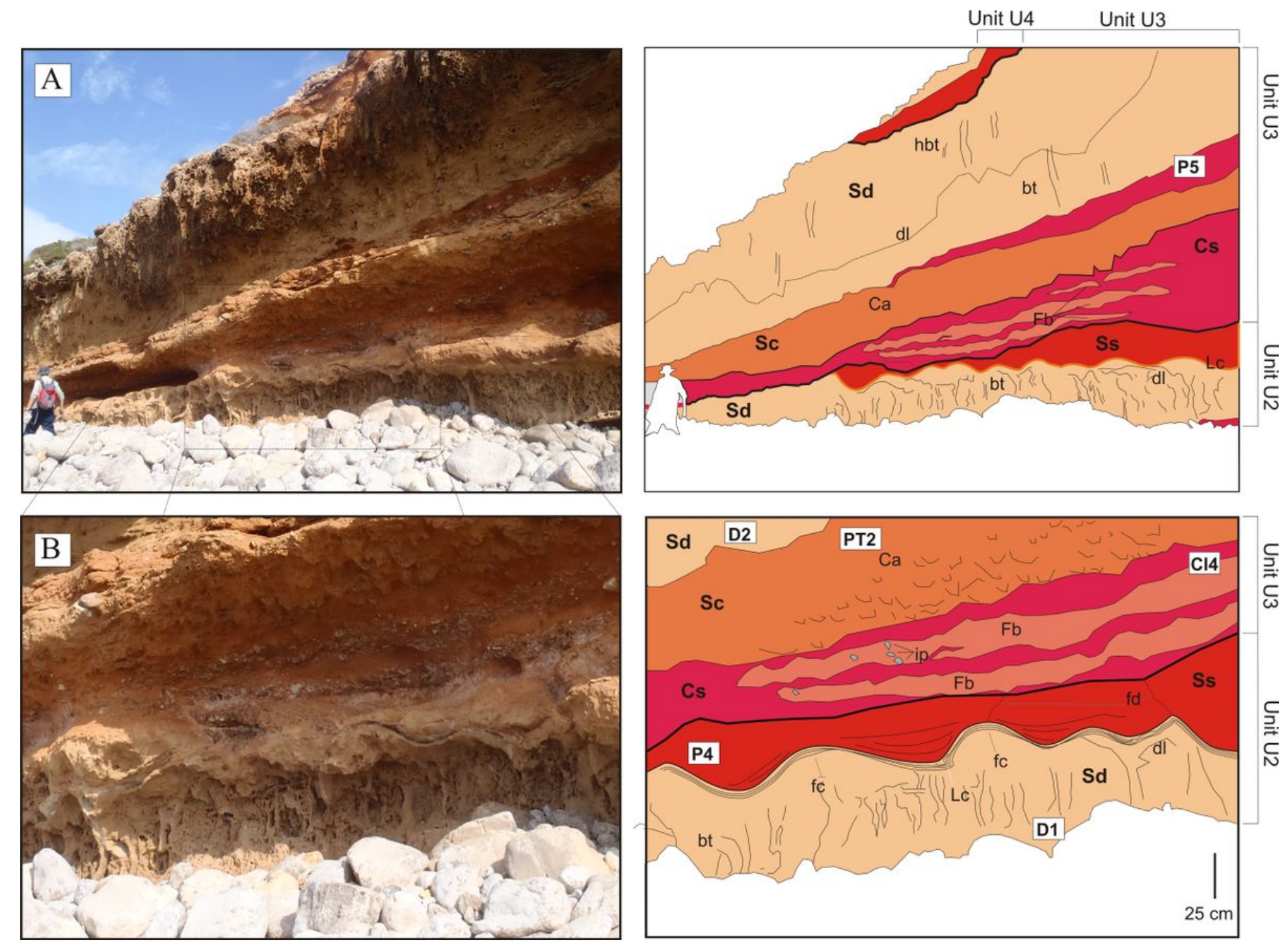

\section{Figure 3}

A) Composite picture and line drawing showing flexis caves ( $\mathrm{fc}$ ), distorted lamination ( $\mathrm{dl}$ ), folded breccia ( $\mathrm{Fb}$ ), imbricated pebbles (ip) and folded dykes (fd) associated with large-scale load structures (Lc). Note the presence of bioturbation (bt), highly bioturbation (hbt) and carbonate nodules (Ca); cryogenic brecciation (Cbt). Lithological characteristics, sandstones (Sd), loamy sands (Sc) and marl (Cs). 

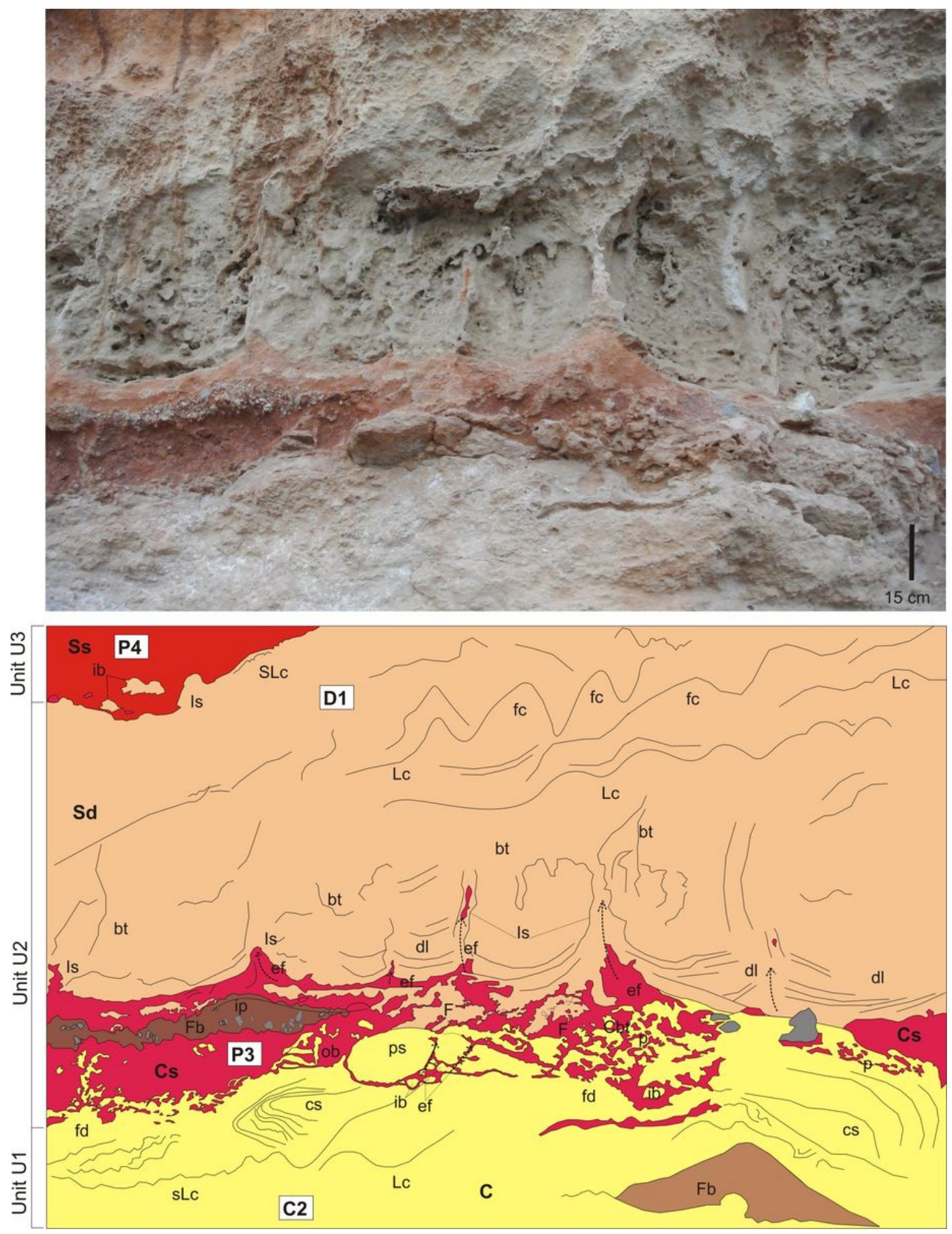

Figure 4

Picture and drawing of deformed deposits of Es Codolar, illustrating several styles of soft-sediment deformation structures overlain by well-stratified deposits. Large-scale load-cast deformation structure (Ld), small-scale load deformation (sLc), folded lamination / distorted lamination (dl), root casts molds from sandstone bed are filled by silty particles - injection structure-(Is), recumbent folds (cs) with parabolic morphology or the axial plane of the folds is subhorizontal; folded dykes ( $\mathrm{fd}$ ), folded breccia ( $\mathrm{fb}$ ); bioturbation with root casts (bt), extrusive flows (ef), flexi caves (fc), isolated block (ib), imbricated pebbles (ip) oriented 
block (ob), flames or pillars (F), pseudonodules continuous (ps); cryogenic brecciation (Cbt). Lithological characteristics: sandstone (Sd), marl (Cs), calcretes (C) and silts (Ss).
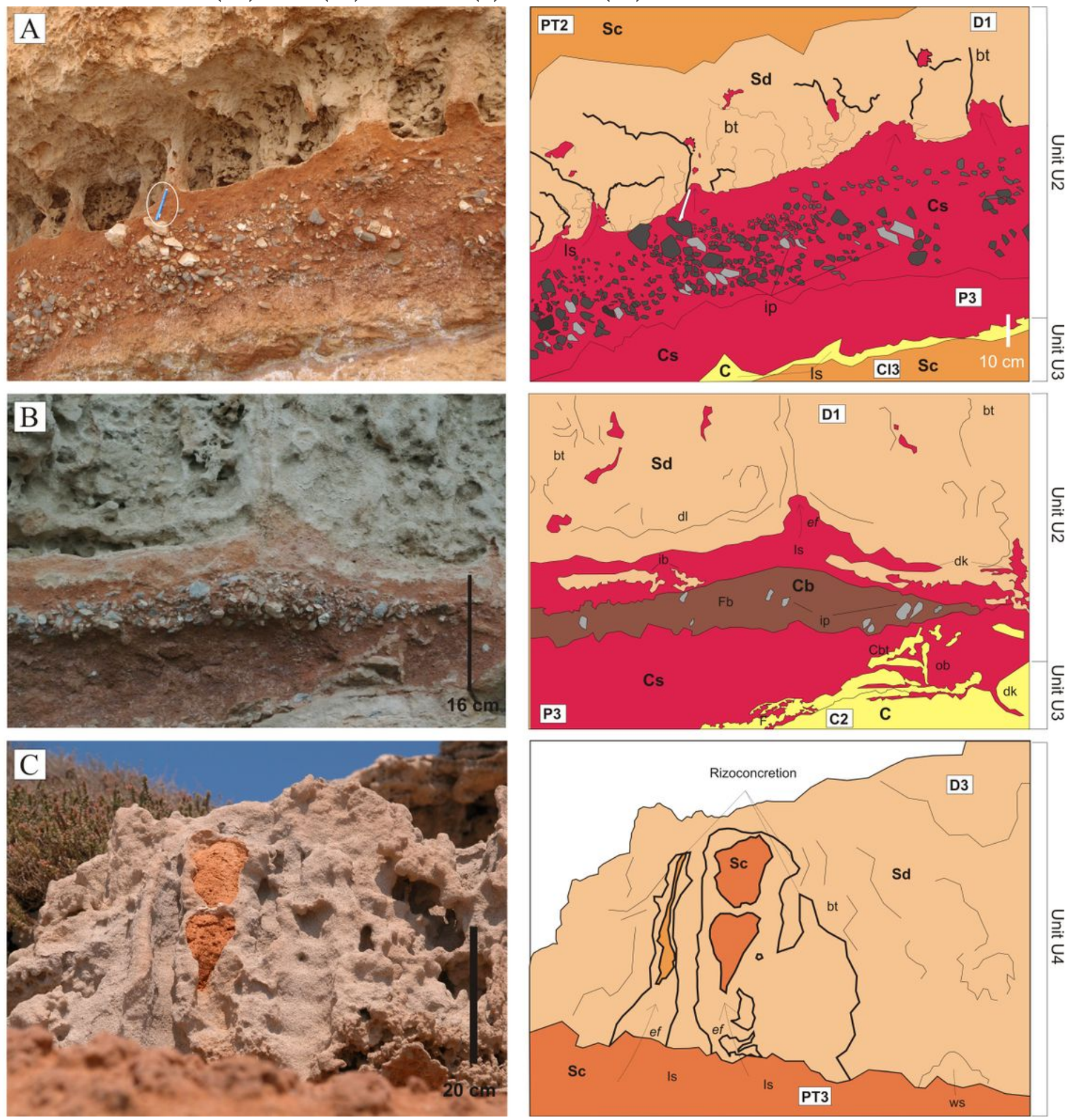

\section{Figure 5}

A) Injection structure, developed in reddish silts (Cs) filling up the root casts molds presents in the sandstone (Sd). Imbricated pebbles and rocks downslope. Note the presence of bioturbation with abundant root casts (3 to $5 \mathrm{~cm}$ width and 0.5 to $1 \mathrm{~m}$ in height). B) Detail of the injection structure, folded breccia (Fb), extrusive flows (ef), imbricated pebbles (ib) oriented blocks (ob), complex of vertical, inclined and sub-horizontal dykes (dk), distorted lamination (dl), cryogenic brecciation (Cbt). C) Detail of injection structure developed in pale brown 
loamy sands filling up the root casts molds $(0.5$ to $5 \mathrm{~cm}$ in width and 0.1 to $0.5 \mathrm{~m}$ in height) presents in the sandstone.
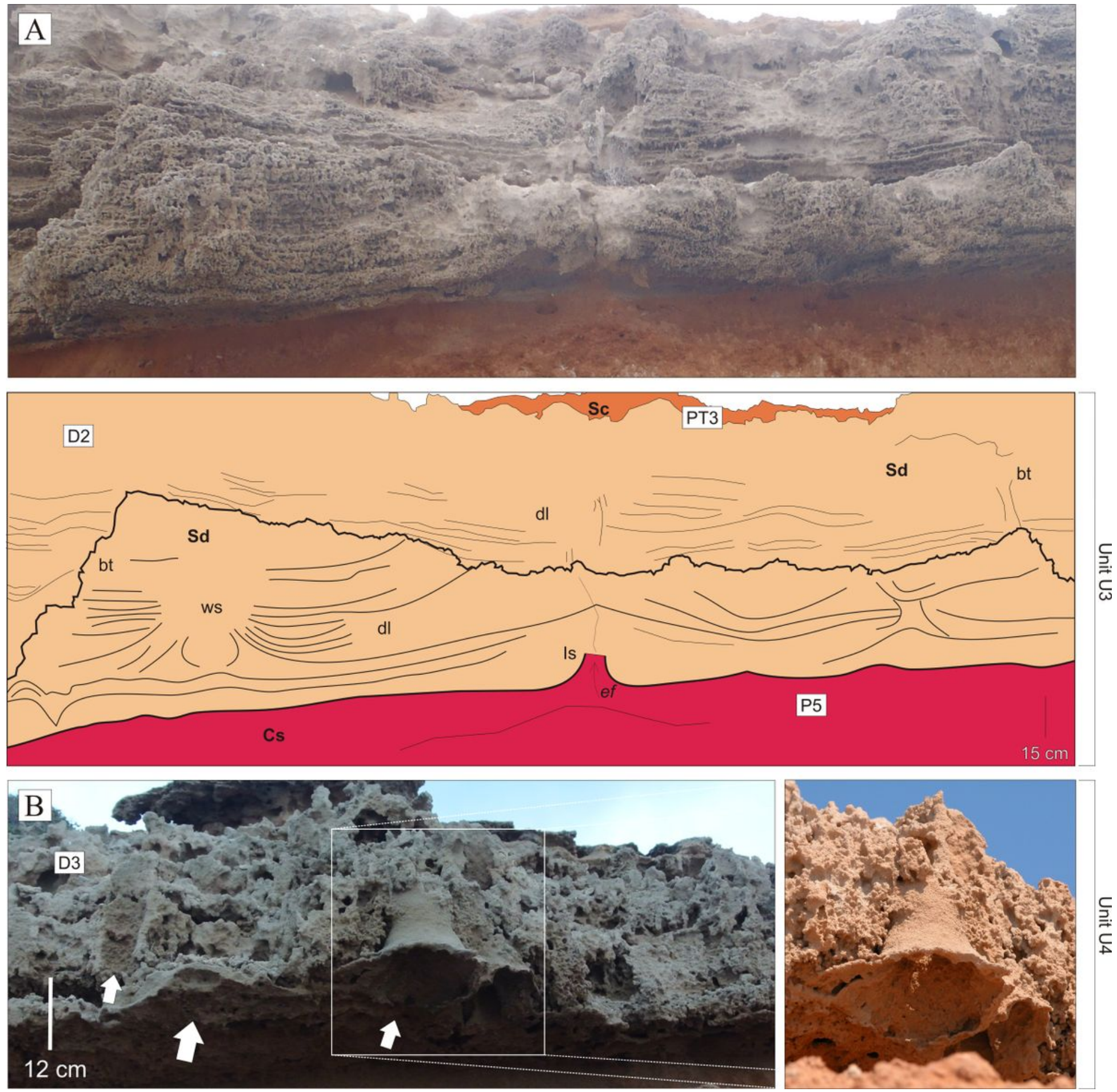

\section{Figure 6}

(A) Water-escape structure developed in a complete deformed sandstone primary stratified bed; extrusive flows (ef), distorted lamination (dl), folded dykes (dk). (B) Empty volcanoes / bell injection deformed structure developed in a complete deformed sandstone bed. Note the high presence of bioturbation with abundant root casts (0.1 to $1.5 \mathrm{~cm}$ in width and 0.10 to $15-20 \mathrm{~cm}$ weight). Lithological characteristics, sandstone (Sd), loamy sands (Sc) and marl (Cs). 

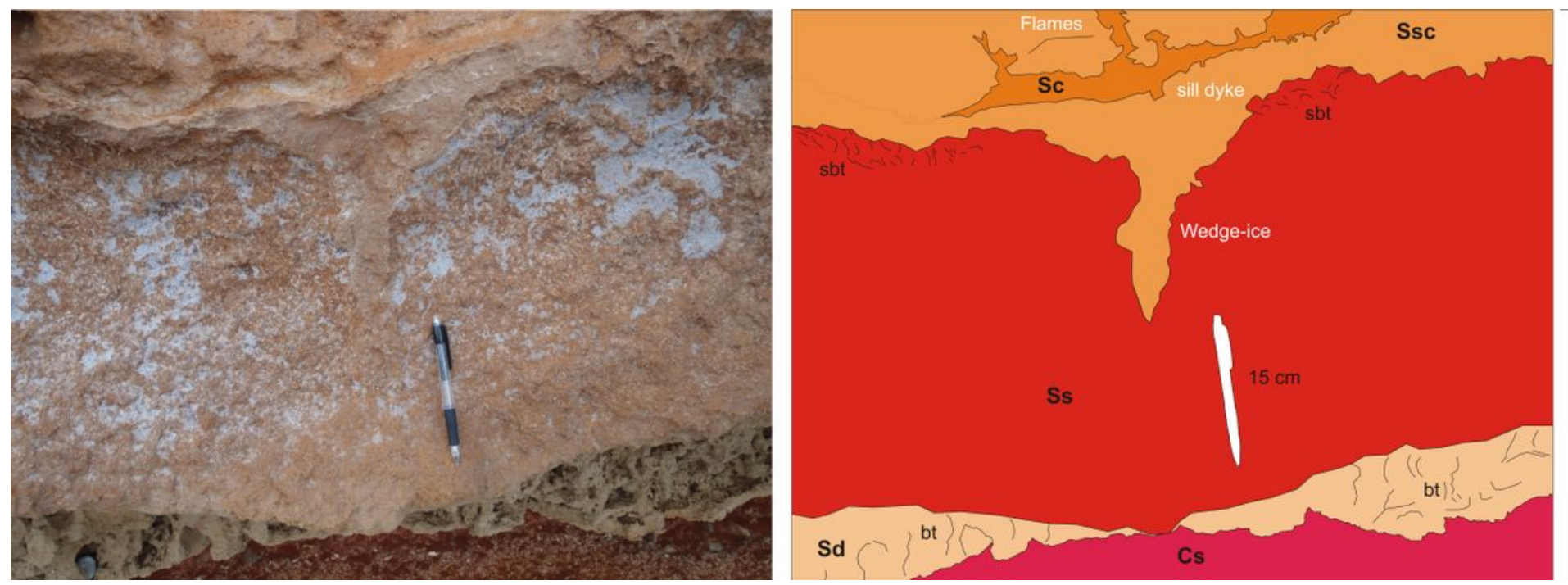

\section{Figure 7}

Picture and line drawing of vertical dykes -Wedge ice-, flame and sill dyke observed at the interface between sandstone (Sd) and silts (Ss). The lower sandstone bed (D1) is completed distorted lamination and filled by silt and clay particles (marl) (Cs) level (P3). Note the presence of small root casts (bioturbation) on top level P4.
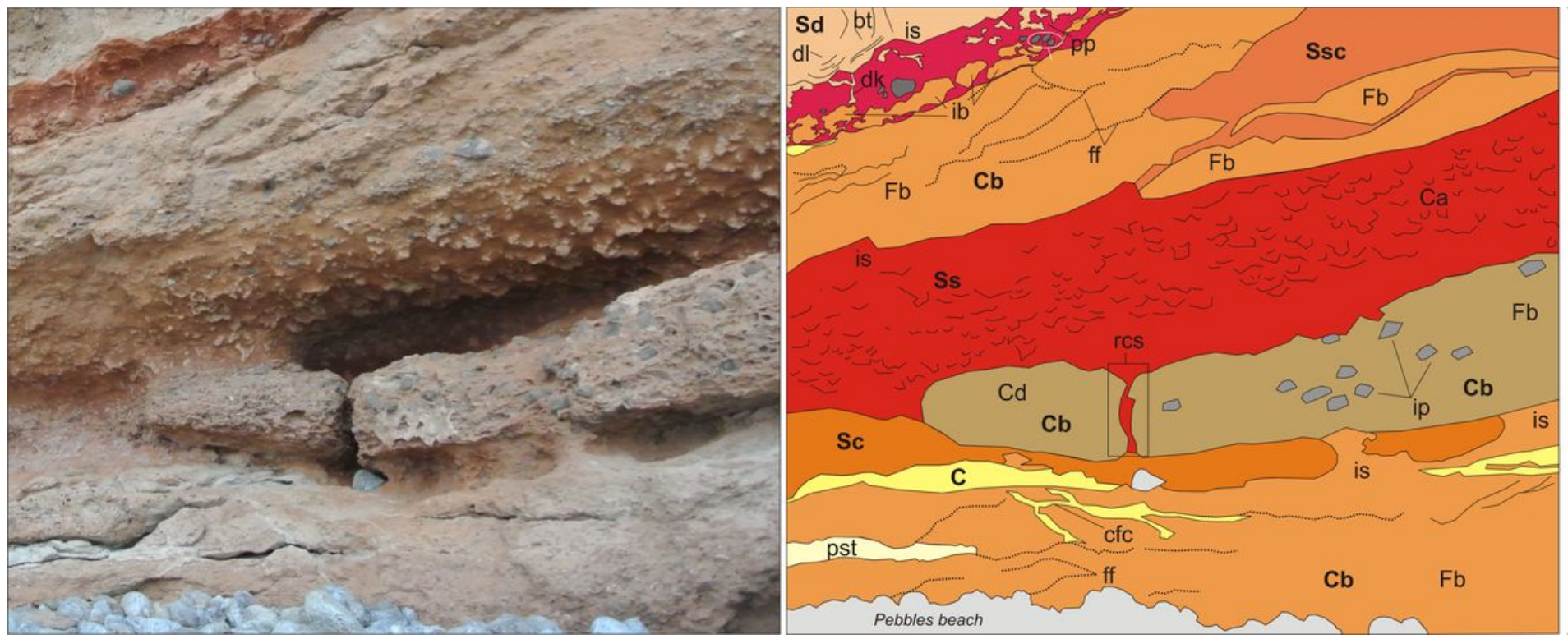

\section{Figure 8}

Picture and line draw showing slope collapse (rcs) and basal slipping, cut dyke (Cd), injection structure (Is), fractured (ff), pisolits (pst), crack filling with calcretes (cfc), folded breccia (fb), imbricated pebbles (ip), isolated block/pebbles (ib), dykes (dk), pillar or small flame (pp), distorted lamination (dl). Note the presence of bioturbation and carbonate nodules. Lithological characteristics, sandstone (Sd), colluvial (Cb), marl (Ssc, Ss), loamy sands (Sc) and calcretes (C). 

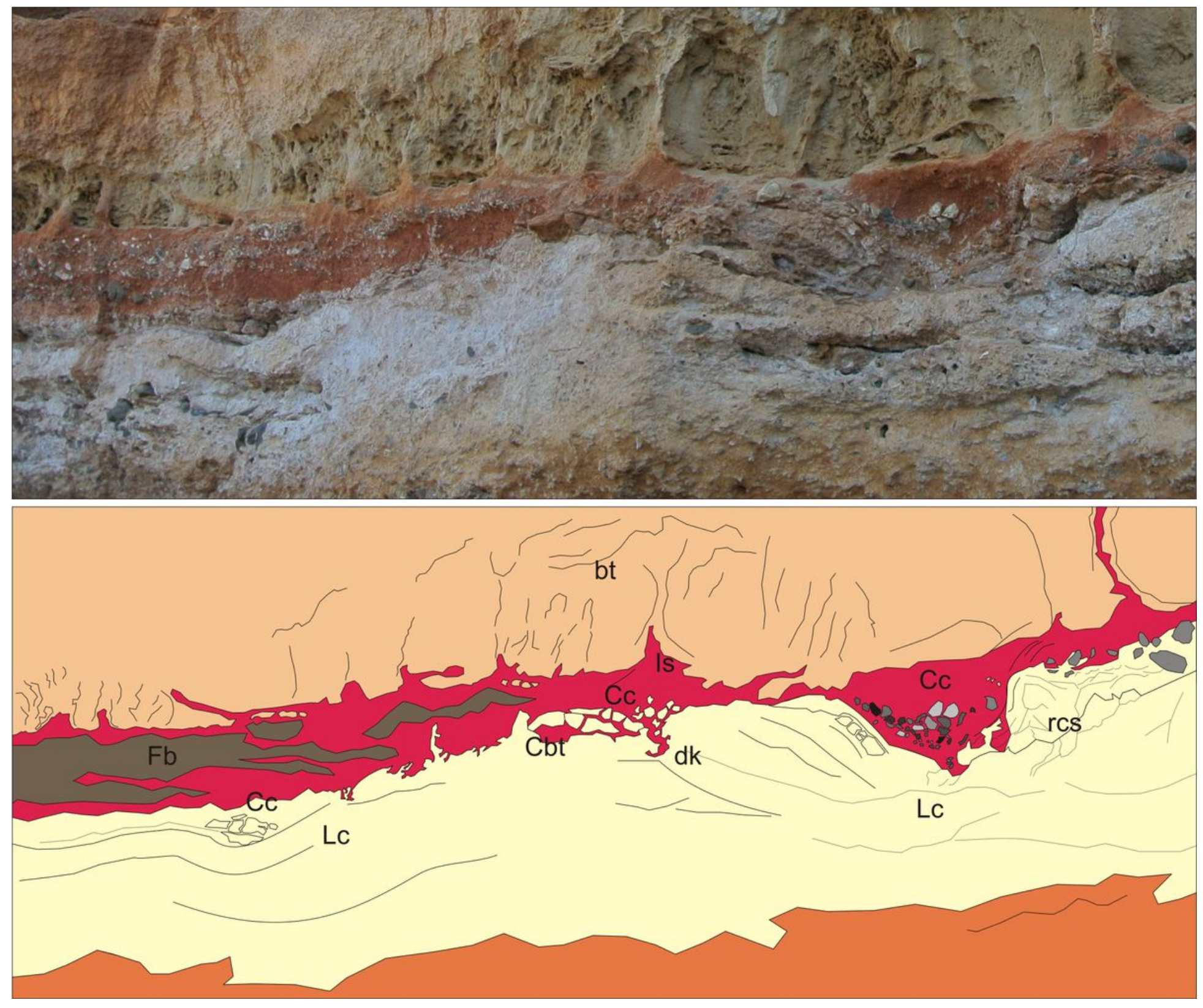

\section{Figure 9}

Picture and line draw of the collapse structure (Cc) associated with the large-scale load structures presence in the outcrops of Es Codolar (Lc); injection structure (Is); slope collapse (rcs), bioturbation (bt), folded breccia (Fb) and dyke (dk); cryogenic brecciation (Cbt).
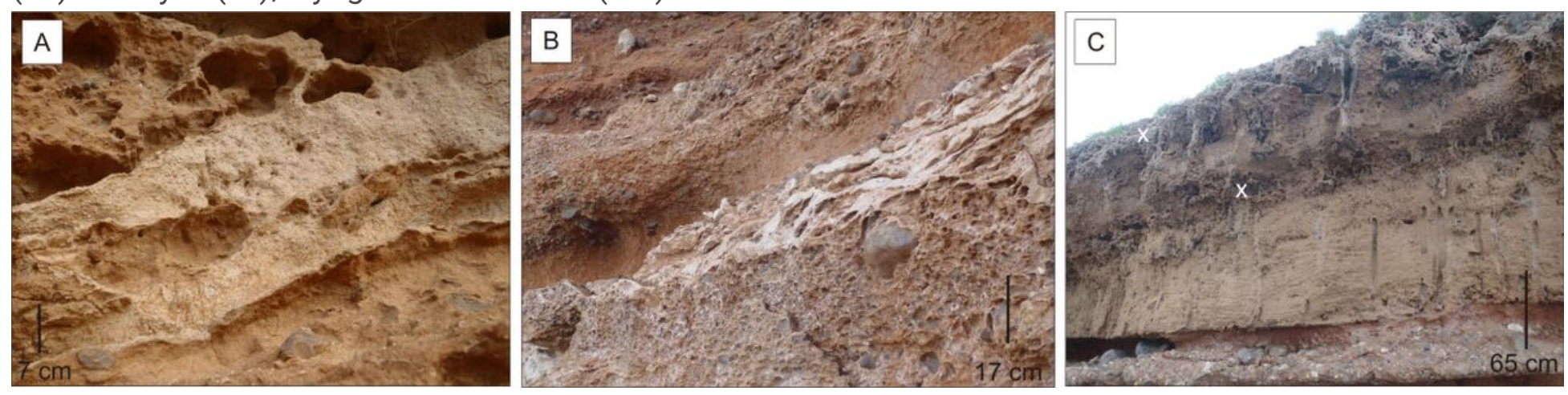
(A) Detail picture of the pisolits level. (B) Calcretes of Es Codolar outcrops. (C) Roots casts and root casts molds ( 5 to $15 \mathrm{~cm}$ in width and $50 \mathrm{~cm}$ to $1 \mathrm{~m}$ in height), the $x$ represents two levels with highly small root casts ( 0.1 to $2.5 \mathrm{~cm}$ in width and 1 to $10 \mathrm{~cm}$ in height approximately).

\begin{tabular}{|c|c|c|c|c|c|}
\hline & \multicolumn{2}{|c|}{$\begin{array}{l}\text { Soft-sediment deformation } \\
\text { structures }\end{array}$} & \multirow{2}{*}{$\begin{array}{l}\begin{array}{c}\text { Mechanisms } \\
\text { deformation }\end{array} \\
\text { Fluidization }\end{array}$} & \multirow{2}{*}{$\begin{array}{c}\text { Driving-force system } \\
\begin{array}{c}\text { Gravitationally unstable } \\
\text { density gradient }\end{array}\end{array}$} & \multirow{2}{*}{$\begin{array}{c}\text { Trigger mechanism } \\
\begin{array}{c}\text { Overloading or periglacial } \\
\text { loading }\end{array}\end{array}$} \\
\hline \multirow{2}{*}{ 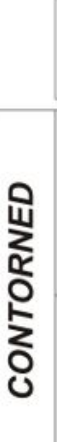 } & Load-cast & & & & \\
\hline & $\begin{array}{l}\text { Recumbent } \\
\text { folds }\end{array}$ & & $\begin{array}{l}\text { Liquefaction / } \\
\text { fluidization }\end{array}$ & $\begin{array}{l}\text { Gravitationally unstable } \\
\text { density gradient and } \\
\text { action drag }\end{array}$ & $\begin{array}{c}\text { Overloading or periglacial } \\
\text { loading }\end{array}$ \\
\hline \multirow{6}{*}{ 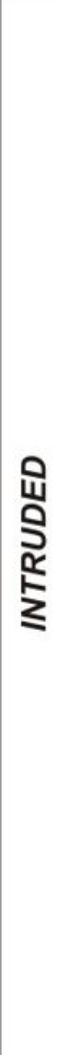 } & $\begin{array}{l}\text { Injection } \\
\text { structures }\end{array}$ & & Liquefaction & Vertical shear stress & $\begin{array}{l}\text { Bioturbation, overloading } \\
\text { and cryohydrostatic } \\
\text { pressure }\end{array}$ \\
\hline & $\begin{array}{l}\text { Water-escape } \\
\text { structures }\end{array}$ & & Liquefaction & $\begin{array}{l}\text { Vertical shear stress and } \\
\text { gravitationally, unstable } \\
\text { density gradient }\end{array}$ & $\begin{array}{l}\text { Overloading, } \\
\text { cryohydrostatic pressure. }\end{array}$ \\
\hline & $\begin{array}{l}\text { Flames and } \\
\text { Pillars }\end{array}$ & & Liquefaction & $\begin{array}{l}\text { Gravitationally unstable } \\
\text { density gradient }\end{array}$ & $\begin{array}{l}\text { Cryohydrostatic pressure } \\
\text { and / or periglacial loading }\end{array}$ \\
\hline & $\begin{array}{l}\text { Dykes, sill- } \\
\text { dyke, pillar }\end{array}$ & & $\begin{array}{l}\text { Liquefaction / } \\
\text { fluidization }\end{array}$ & $\begin{array}{l}\text { Gravitationally unstable } \\
\text { density gradient }\end{array}$ & $\begin{array}{l}\text { Cryohydrostatic pressure } \\
\text { and/or periglacial loading }\end{array}$ \\
\hline & Wedge-ice & & $\begin{array}{l}\text { Liquefaction / } \\
\text { cryoturbation }\end{array}$ & $\begin{array}{l}\text { Vertical body force and } \\
\text { freezing }\end{array}$ & $\begin{array}{l}\text { Periglacial loading and/or } \\
\text { cryohydrostatic pressure }\end{array}$ \\
\hline & $\begin{array}{l}\text { Cryogenic } \\
\text { brecciation }\end{array}$ & & $\begin{array}{l}\text { Liquefaction / } \\
\text { Fluidization / } \\
\text { cryoturbation }\end{array}$ & $\begin{array}{l}\text { Vertical body force and } \\
\text { freezing }\end{array}$ & $\begin{array}{l}\text { Periglacial loading and/or } \\
\text { cryohydrostatic pressure }\end{array}$ \\
\hline \multirow{2}{*}{ 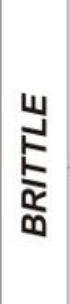 } & Slope collapse & & $\begin{array}{l}\text { Rugged cut } \\
\text { slump }\end{array}$ & $\begin{array}{l}\text { Gravitational body } \\
\text { pressure and steep slope }\end{array}$ & $\begin{array}{l}\text { Action drag and } \\
\text { overloading }\end{array}$ \\
\hline & $\begin{array}{l}\text { Collapse } \\
\text { structures }\end{array}$ & & Overload & $\begin{array}{l}\text { Gravitational body } \\
\text { pressure }\end{array}$ & $\begin{array}{l}\text { Overloading and } \\
\text { cryohydrostatic pressure }\end{array}$ \\
\hline
\end{tabular}

Figure 11

Classification of the soft-sediment deformation structures described at Es Codolar succession. Different driving force systems, deformation and trigger mechanisms for each kind of soft-sediment deformation 
structure are presented.

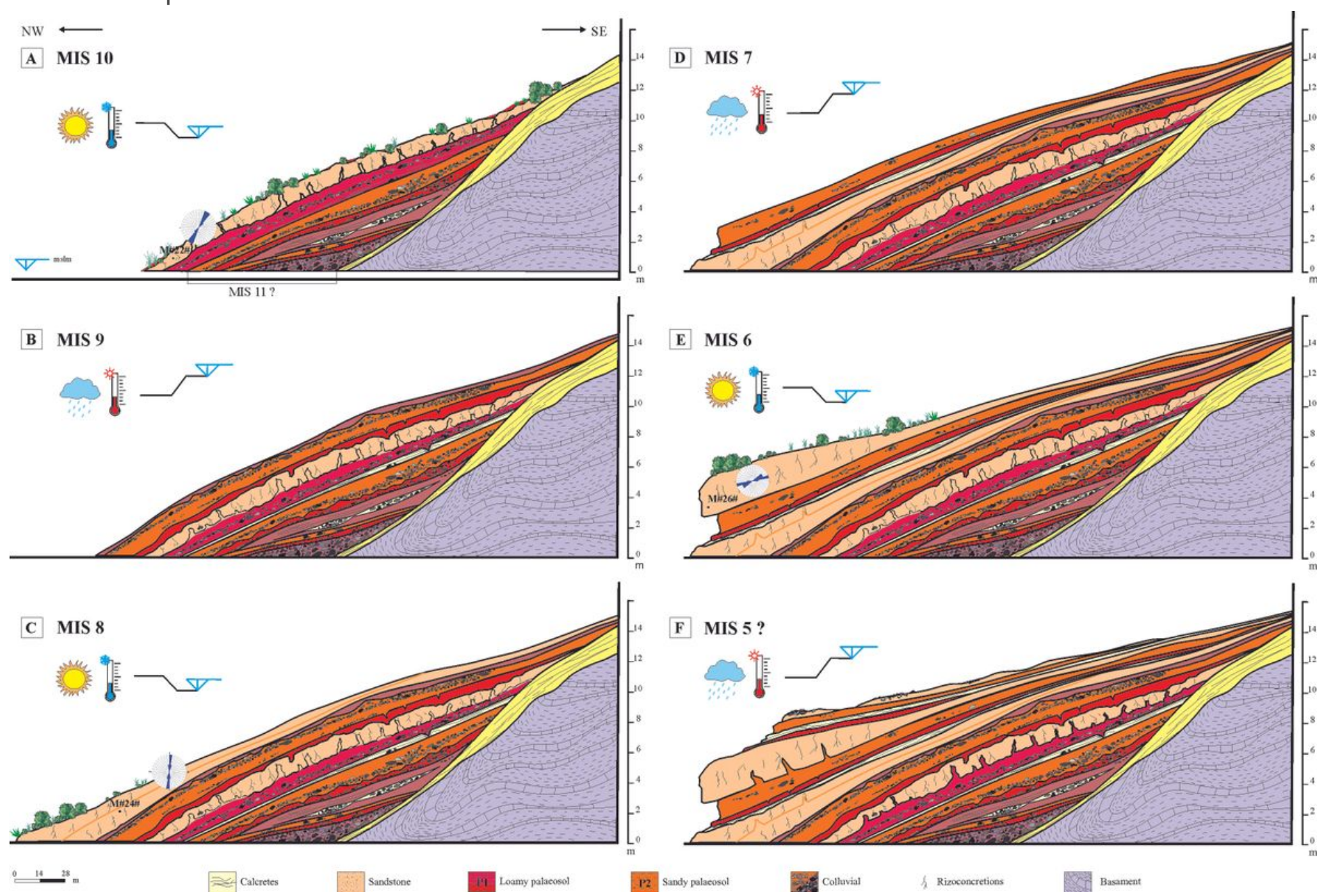

Figure 12

Depositional environment evolution model showing the succession of the main sedimentary environments, paleocurrent directions of the western coast of Eivissa from MIS 10 to MIS 5 and the soft sediment deformations. 


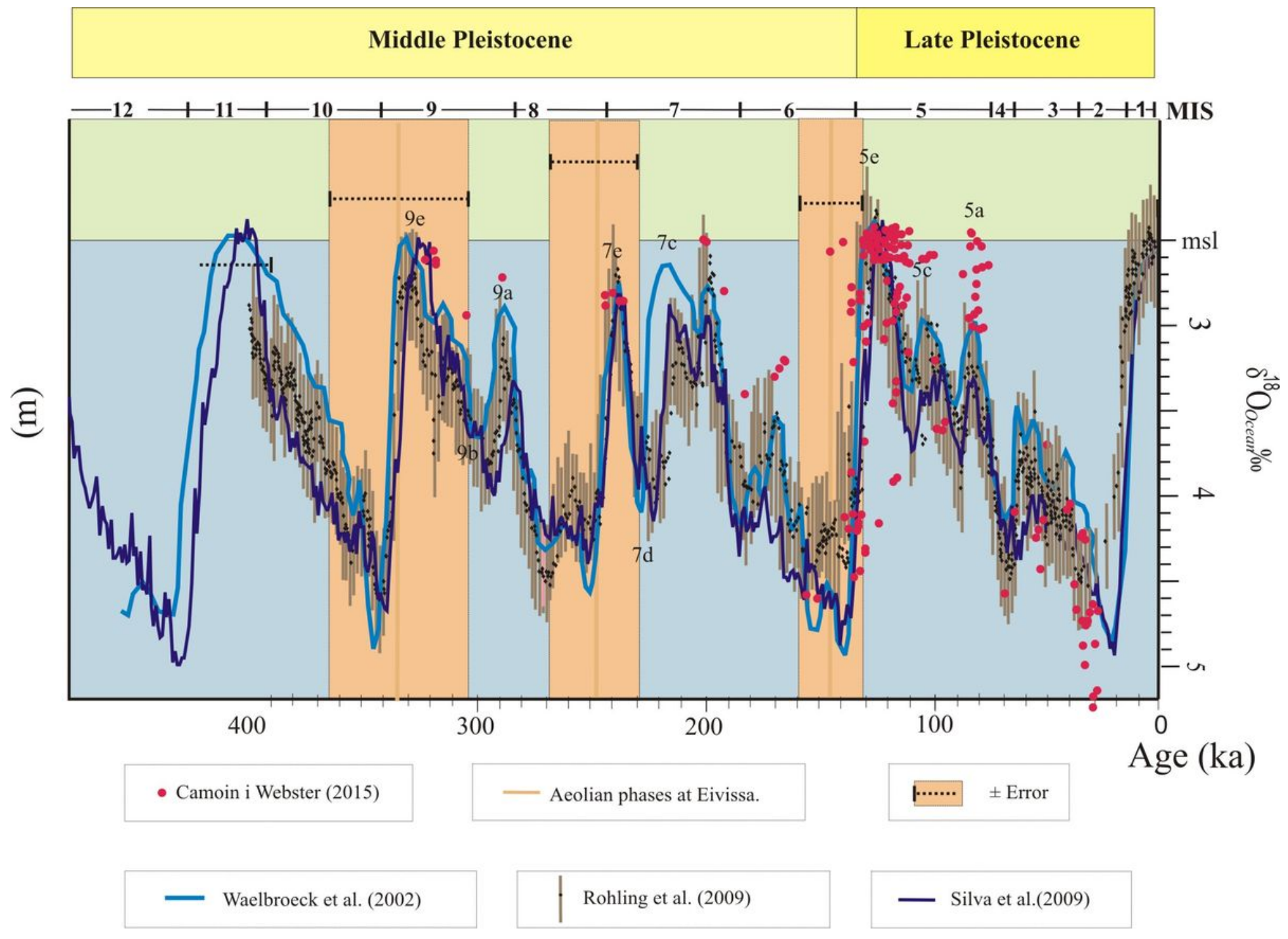

Figure 13

Sea level reconstructions for the last $500 \mathrm{Ka}$ based on continuous records of 018 benthic by Silva et al., (2009); sea level reconstructions for the last 500 Ka based on continuous records, compiled from the Red Sea by Rohling et al., (2009 and 2012); 018 benthonic registers present in the deep waters of Waelbroeck et al., (2002); coral reefs register for Camoin and Webster (2015) and representation of the periods of aeolian sedimentation on the island of Ibiza based on the absolute OSL dating performed here, shaded in pale brown. The black line symbols represent the OSL age +/- error. 